Review

\title{
Brief comparison of the mechanism of modern medicine and traditional medicine in neuronal cell death
}

\author{
Young-Sick Kim ${ }^{1}$, Hyun-Ja Jeong ${ }^{2}$, Hyung-Min Kim ${ }^{1}$, Seung-Hun Cho, \\ ${ }^{1}$ Department of Pharmacology, College of Oriental Medicine, Kyung Hee University, 1 Hoegi-dong, Dongdaemoon-gu, Seoul, 130 - \\ 701, Republic of Korea; ${ }^{2}$ Biochip Research Center, Hoseo University, Asan, Chungnam, 336-795, Republic of Korea; ${ }^{3}$ Department \\ of Neuropsychiatry, College of Oriental Medicine, Kyung Hee University, 1 Hoegi-dong, Dongdaemoon-gu, Seoul, 130-701 Republic \\ of Korea
}

\begin{abstract}
Medicine has a past, a present, and will have a future; the same can be said for many diseases. Even with the surprising development of modern medicine, traditional medicine, especially eastern Asian traditional medicines still exist and are widely used in those regions. But modern medicine and western pacific traditional medicines have different theories and applications for the same disease. In this review, traditional medical theory, used together with modern medicine, can be combined to shed light on the area of neuronal death.
\end{abstract}

Keywords traditional medicine, neuronal cell death, excitotoxicity, p53, tonifying qi, tonifying kidney

\section{INTRODUCTION}

Neuronal diseases have existed for a long time and include tremors, strokes, unconscious states and depression. In the last century, modern medicine has developed surprisingly in terms of treatments. In addition, the developments in medicine have led to many more discoveries of diseases. As advanced diagnosis and diagnostic tools are more accurate, medicine can reveal distinct diseases. Even with these advances and developments, many questions remain unanswered regarding human beings, how many of these diseases occur, and how to treat them. Neuronal death, especially in central nervous system (CNS) associated diseases, exacts heavy health and social tolls. Major diseases of neuronal death result from accidents such as traumatic brain injury (TBI) and stroke (or apoplexy), or chronic neurodegenerative diseases such as Alzheimer's disease (AD) and Parkinson's disease (PD). Many studies have been undertaken about them, but it is hard to prevent and predict occurring times and difficult to control the diseases once they have occurred. One of reason is CNS is not fully understand although many of studies have been done.

In eastern Asia traditional medicine, it is hard to specifically explain the medical theory. The major reason is that most core medical terms used to explain medical theory come from philosophy. In addition, many of meanings are compressed in a word and a character. For this reason, traditional medicine is able to give the same cure strategy and to give the many of alternative treatments for the same patient. These are the reasons that to the outsider, in terms of not being an eastern Asia traditional medicine practioner, traditional medicine seems unscientific. Nevertheless, traditional medicine can be effective. In the last century, the sudden change of traditional values has meant the losing of the proper value of traditional medicine. In the following manuscript, there will be

\section{${ }^{*}$ Correspondence: Seung-Hun Cho}

E-mail: chosh@khu.ac.kr

Received May 21, 2011; Accepted November 29, 2011; Published November, 30, 2011

doi: http://dx.doi.org/10.5677/tang.2011.0001

C2011 by Association of Humanitas Medicine a brief description of modern and traditional medicine related to neuronal death.

\section{Neuronal death}

Neuronal death is divided largely two parts: accidentally occurring neuronal death and chronically progressing neuronal death. The accidentally occurring neuronal death such as TBI by car accident or hemorrhage and is a hard to control neuronal death at the occurring time. When occurring, mainly the physical stress and damage induce neuronal cell death immediately. The chronically progressing neuronal death such as PD or debris from TBI induced secondary cell death is the target of medical care to control or delay progressive neuronal cell death (Zhang et al., 2005).

\section{Excitatory neuronal transmitter - Glutamate-NMDA}

Glutamate is a major excitatory neurotransmitter in CNS and its receptors are classified as ionotrophic receptor (iGluR) and metabotrophic receptor (mGluR). iGluR plays a role by the entrance of $\mathrm{Na}^{+}$and $\mathrm{Ca}^{2+}$, divided subtype N-methyl-Daspartate (NMDA) receptor (NR), $\alpha$-amino-3hydroxyl-5methyl-4-isoxazole-propionate (AMPA) receptor and kainate receptor; mGluR plays a role as the second messengers coupled with G-proteins, divided group I mediated 1,4,5-inositol three phosphate $\left(\mathrm{PIP}_{2}\right) /$ diacylglycerol (DAG) linked with phospholipase C (PLC) and group II and III mediated cyclic adenisine mono phosphate (cAMP) linked adenylate cyclase. Glutamate receptors play a crucial role in the physiological condition, but do the same as the pathological condition, called "excitotoxicity" (Verkhratsky and Kirchhoff, 2007).

Excitotoxicity is usually observed in ischemic damage. Ischemic damage is able to occur where blood circulation and reperfusion damage usually follow an ischemia and are called ischemia/reperfusion ( $I / R)$ damage. Especially, $I / R$ damage in CNS is considered to be serious because once the damage has occurred, it is irreversible, rarely reparable and the function of the lesion is irreplaceable. When the ischemic attacks, reduces or blocks blood circulation, then ATP runs out and the neuronal membrane is depolarized and glutamate is released from the excitatory neuron. This glutamate activates glutamate receptors, especially enhanced $\mathrm{Ca}^{2+}$ influx to cytosol through a NMDA 
receptor and it results in mitochondrial dysfunction and excessive nitric oxide synthase, NO expressions and reactive oxygen species (ROS) that are induced by NO. In this time, blood reperfusion and normal $\mathrm{O}_{2}$ supplement lead to excessive $\mathrm{NO}$ production and ROS by NO. Finally, $\mathrm{Ca}^{2+}$ overload and excessive ROS leads to neuronal death (Gunasekar et al., 1995; Nicholls and Attwell, 1990; Simon et al., 1984; Tong et al., 1995). This NMDA induced neuronal death appears in a secondary neuronal death such as traumatic brain injury. After the physical damage, lesions occurring necrosis at the time, and necrosis takes out the inner cell components, and they lead to inflammation mediated or direct NMDA receptor stimulated neuronal death. Also, the chronic neuronal diseases are mediated NMDA receptors such as PD or AD (Kleen and Holmes, 2010; Wennersten et al., 2003).

\section{p53 and neuronal death}

Since discovery of the p53 gene that suppressed tumorigenesis, this nuclear phosphoprotein functions as a key regulator of cell cycle progression and apoptosis. Also, it is believed that p53 responds properly when DNA was damaged, whether it is reparable or not (Smith and Kumar, 2010). Loss or inactivation, such as with the mutation of the p53 tumor suppressor gene, occurs in about half of all human tumors (Greenblatt et al., 1994) and is at a higher risk for developing variants tumors (Malkin et al., 1990; Srivastava et al., 1990). The p53 protein is upregulated by variants' cellular stresses, such as DNA damage, hypoxia, oxidative stress, ribonucleotide depletion and oncogene activations (Giaccia and Kastan, 1998; Ko and Prives, 1996). The effects of p53 are apoptosis mediated by p53upregulated modulator of apoptosis (PUMA), and cell protection through the arrest of the cell cycle by cyclindependant kinase (CDK) inhibitor p21 activation. Especially, a strong p21 mediated cell cycle arrest is called senescence (Vousden and Prives, 2009). Up-regulation of p53 is a phosphorylated different site that damage-defendant dependant manner, it decides the fate of cell apoptosis or survival including senescence.

The absence of p53 has been shown to have neuroprotective effects in vivo from a wide variety of toxic matters including focal ischemia (Crumrine et al, 1994), ionizing radiation (Herzog et al., 1998; Wood and Youle, 1995), MPTP-induced neurotoxicity, methamphetamine- induced neurotoxicity (Trimmer et al., 1996) and adrenalectomy (Hirata and Cadet, 1997). p53 is also essential for developmental neuronal death (Aloyz et al., 1998). The generally occurring developmental cell death of sympathetic neurons is dramatically reduced in p53 -/- and even in p53 +/- animals. Cultured neurons with both $\mathrm{p} 53$-/- and $\mathrm{p} 53+/$ - exert protective effects on toxins that include DNA damaging agents (Anderson and Tolkovsky, 1999; Araki et al., 1998; Chen et al., 1999; Enokido et al., 1996A; Enokido et al., 1996A; Xiang et al., 1998), ionizing radiation (Enokido et al., 1996B; Johnson et al., 1998), glutamate (Urberti et al., 1998; Chen and Chuang, 1999; Xiang et al., 1996), hypoxia (Banasiak and Haddad, 1998; Halterman et al., 1999), and NGF withdrawal (Aloyz et al., 1998; Vogel and Parada, 1998). In contrast, neurons lacking p53 die when transferred to a low potassium medium (b Enoido 1996A) or postnatal cortical and hippocampal neurons also die after staurosporine exposure in a p53-independent manner (Johnson et al., 1998). But the inhibition or absence of p53 does not mean against all forms of toxic insults. (Kuntz et al., 2000; Wood an Youle, 1995).

As described above, p53 plays a key role in excitotoxic cell death and is now generally recognized, but there are exceptions occasionally. In the seizure model by systemic injection of kainic acid, the expression of p53 is a well defined excitotoxic cell death pattern and there is evidence of damaged neurons
(Sakhi et al., 1994; Sakhi et al., 1996). Also, p53 KO mice demonstrated that p53 induction was co-related to excitotoxic neuronal death (Morrison et al., 1996). But Schauwecker and Steward (1997) suggested that less damage in the p53-deficient mice might be due to the relative presence of a protective gene(s) in the C57BL/6 mice strain of the p53 deficient mouse line (Donehower et al., 1992). They reported that the wild type C57BL/6 mice did not show evidence of neuronal damage in the CA3 or CA1 subregion (Schauwecker and Steward, 1997). In addition, another independent p53-deficient mouse line did not show a protective effect against excitotoxic neuronal death in the kainate induced seizure model (Lowe et al., 1993). C57BL/6 mice are known to be less sensitive to kainateinduced seizures (Engstrom and Woodbury, 1988; Ferraro et al., 1995) and seizure induced damage (Royle et al., 1999), and it is reported there is a significant induction of neuronal damage in the CA3 and CA1 of the hippocampus in C57BL/6 mice in kainite induced seizures (Hu et al., 1998; Hertel et al., 2000). Thus, p53 is one of major factor in exctotoxic neuronal death but some p53 independent excitotoxic pathways could exist. For greater details, it is recommended to read about p53 and neuronal cell death in the review of Morrison and Kinosihta (2000).

\section{p53 inhibitor, potential protective drug for exctotoxicity} induced neuronal death

Excitotoxicity in the brain has a well known mechanism for how to diminish damage or lesions. However, the proper drug does still not exist so that excitotoxicity is induced by internal neurotransmitter that it is too dangerous to block excitatory neuronal signals. If the excitation blockage is not enough, it does not prevent damage. Or fully blockages will cause heart arrest or eternal neuronal depression.

The hint of preventing or attenuating damage from excitotoxicity is in the ion. The NMDA receptor and voltage activated $\mathrm{Ca}^{2+}$ channel (VACC) are major $\mathrm{Ca}^{2+}$ supplements from the extracellular matrix and related to excitotoxicity. Magnesium ions play the cap of the NMDA receptor in normal conditions. Indeed, the administration of magnesium has been shown to have neuroprotective effects and significantly reduce p53 mRNA in an experimental traumatic brain injury model (Muir et al., 1999). It is reported that lipophilic dihydropyridine VACC blockers, which can cross over the brain-blood-barrier, are about $30 \%$ decreased in PD compared with other $\mathrm{Ca}^{2+}$ channel blockers in Denmark (Ritz et al., 2010), and $\mathrm{Ca}^{2+}$ passed by the L-type $\mathrm{Ca}^{2+}$ channel plays a critical role in selective dopaminergic neurnal death in substnatia nigra pas compacta (SNpc) (Mosharov et al, 2009). But ion control is hard and dangerous. Endothelial nitric oxide synthase (eNOS) expression is beneficial to $\mathrm{AD}$ but eNOS expression related to $\mathrm{Ca}^{2+}$ channel (Lange-Asschenfeldt, 2008), and $\mathrm{Ca}^{2+}$ channel blockage inhibits ischemic damage induced hippocampal dentate gyrus neurogenesis (Luo et al., 2005). In addition, treatment of the ion channel blocker must be done carefully because the same ion channel may have different roles in other tissues, and adverse effects may be critical in terms of the effects on the whole excitatory tissue, like heart arrest.

Accordingly, it is natural to be concerned with the blockage of p53 signaling and inhibition rather than the blockage of excitatory receptors and finding the reliable excitatory receptor blocker. Especially, excitatory amino acids or their receptor agonists have been strongly associated with p53 accumulation. This means p53 inhibition might be a good choice of method for reducing excitotoxicity induced cell death. Treatment of hyperthermia diminishes apoptosis and p53 expression, and p53 induced apoptotic proteins in $\mathrm{I} / \mathrm{R}$ ischemia that induced neuronal death (Eberspächer et al., 2003; Eberspächer et al., 2005). Also, there is the case of pifithrin- $\alpha$, which is a p53 and 
DNA binding inhibitor and inhibits cerebral ischemia (Leker et al., 2004). It not only inhibits the cerebral ischemia but also attenuates myocardiac infarction (Liu et al., 2006) and renal ischemic apoptosis (Dagher, 2004). It is reported that myocyte apoptosis in the myocardial infarction and p53 had no relation (Bialick et al., 1997), but p53 did not affect myocyte apoptosis during infarction conditions, nor the p53 inhibitor pifithrin- $\alpha$ attenuate myocardial infarction after apoptosis. Except for exctitotoxicity and p53, a neuroinflammatory mechanism is also suggested. But there have not been enough study cases related to traditional medicine for the purpose of this review, so the subject has been excluded.

\section{Neuronal disease in traditional medicine}

Traditional medicine exists in all countries. In this review, traditional medicine is focused eastern Asia traditional medicine. Indeed, there is no exact concept of brain damage, but there is the similar concept called brain deficiency in traditional medicine. In traditional medicine, the brain and spinal cord are attached to the kidney, which is different from physiological kidney functions, and qi means life and activity, so it is the most important in life. In a brain deficiency, tonifying qi and the kidney are important to care and recovery, or the elimination of residua from it. But there is no way to measure the activity or regulation of qi and the traditional medical kidney. Fortunately, there are studies about classical herbs and herbal formula for tonifying qi and the kidney.

\section{Radix Ginseng for tonifying qi}

Different from the single herb, the herbal formula is difficult to study since it involves such a large number of substances. As a result, many studies have focused on a single herb rather than on a herbal formula. For example, the root of Panax Ginseng C.A. MAYER, Ginseng Radix, is one of the well-known and well-studied herbs. Also, it is one of the important qi-tonifying herbs. Its range of effects include on CNS, behavior, lipid/carbohydrate metabolism, endocrine system, sexual development, immune, anti-tumor, hematopoietic function, renal disorder, anti-narcotic and application shock, diabetes mellitus, neurological symptoms and mental fatigue. (You-Ping Zhu, 1998)

Focusing on CNS, ginseng or its substances inhibit glutamate receptors including NMDA receptors (Kim et al., 2004; Bao et al., 2005; Lee et al., 2006; Kim et al., 2007; Zhao et al., 2009). Similarly, it is reported that ginseng attenuated NMDA-mediated epileptic discharge damage (Kim and Rhim, 2004), glutamate induced excitatory stress in dopaminergic cells (Radad et al., 2004), and alcohol induced neuronal death and memory impairment (Bao et al., 2005). In addition, it has improved morphine induced learning impairment (Qi et al., 2009) and age-induced memory impairment (Gu et al., 2009). In general, compensational neurogenesis is usually activated in a brain damage lesion dependant manner (Zhang et al., 2005), and it is reported that ginseng attenuated focal ischemia induced lesions and an increase of compensational neurogenesis (Ye et al., 2011; Zheng et al., 2011). It has an exerted protective effect in the MPTP and $\mathrm{MPP}^{+}$induced PD models (Van Kampen et al., 2003), especially ginsenoside Rb1 suppressed MPTP and rotenone induced dopaminergic cell death by its anti-oxidative effect (Chen et al., 2005; Leung et al., 2007). Likewise, ginsenoside Rb1 reduced 6-OHDA and MPP+ induced iron uptake in MES23.5 cells (Xu et al., 2010A; $\mathrm{Xu}$ et al., 2010B). Ginseng saponins also inhibit the L-type $\mathrm{Ca}^{2+}$ voltage activated $\mathrm{Ca}^{2+}$ channel (L-VACC), which is one of major factors for selective dopaminergic cell death in SNpc (Mosharov et al., 2009) induced rat cortical neurons (Kim et al., 2008). Youdim (2008) reviewed that iron ion deficiency and excess can cause neurodegenerative diseases like AD and PD.
In $\mathrm{AD}$, ginsenoside $\mathrm{Rb} 1$ attenuated $\mathrm{A} \beta(1-42)$ and tau phosphorylation induced neurotoxicity in cortical neuron cultures (Zhao et al., 2011) and neuroinflammation in rats (Wang et al., 2011). The acidic polysaccharide of ginseng decreased gamma radiation induced p53 and Bax expressions and increased Bcl 2 expression (Park et al., 2011); the ethanol extract of ginseng has a much stronger anti-cancer effect via normal water extract regulation of ERK-p53 and NF- $\kappa B$ in mouse Lewis lung carcinoma (Wong et al., 2010). All of these cases taken together, ginseng have attenuation of excitotoxicity induced by glutamate or NMDA, L-VACC blockage, antioxidative effect, and p53 and Bax suppression and enhancing Bcl-2 family.

\section{Liuwei Dihuang wan for tonifying the kidney}

Liuwei Dihuang wan (LWDH), one of the most famous Chinese traditional medicines, is widely used in eastern Asia and it consists of Rehmanniae Radix, Dioscorae Radix, Corni fructus, Alimatis Rhizoma, Paeoniae suffruticosa Cortex, and Poria. It used for kidney deficiency, and kidney functions are the control of bone, fluid, reproduction, and CNS. It has many derivative varieties by adding a few herbs and sometimes called by another name, espeacally sheqi wan, which is called by adding Schisandrae fructus, or Aconiti Tuber and Cinnamomi Cortex, or all three of them with LWDH. In China, there are hundreds of medicinal manufacturers which produce Liuwei Dihuang Pills based on LWDH, and its derivative varieties, such as Zhibai Dihuang Pills, Guifu Dihuang Pills, Mingmu Dihuang Pills, Qiju Dihuang Pills, Maiwei Dihuang Pills, and Guishao Dihuang Pills. (Xue et al., 2005; Zhao et al., 2007). However, there are few studies that have compared them to each other in English. Also, the above described LWDH and its variants using shenqi wan also are called the abbreviated LWDH.

Protective effects against cell death of LWDH are femoral head necrosis and/or apoptosis (Li et al., 2010; Liu et al., 2010) and $\mathrm{H}_{2} \mathrm{O}_{2}$ induced hippocampal neuron apoptosis (Shin et al., 2003). Also, it is reported that the up-regulation of Bcl-2 mRNA and down-regulation of Bax mRNA in OLEF rat pancreas (Xue et al., 2005). LWDH improved scopolamine and p-chloroamphetamine -induced amnesia induced amnesia (Hsieh et al., 2003). In a senescence accelerated mouse hippocampus, LWDH might facilitate cognition by genes' expressions (Chang et al., 2007). But $\mathrm{H}_{2} \mathrm{O}_{2}$ induced DNA damage was suppressed by a single treatment of herbs that are components of LWDH, but LWDH as a herbal formula was not successful (Szeto et al., 2009). Also, Yang et al. (2006) reported that $\mathrm{LWDH}$ suppressed $\mathrm{K}^{+}$and $\mathrm{Ca}^{2+}$ ion currents in cultured rat hippocampal neurons, and Shin et al. (2003) reported that shenqi wan diminished glutamate and NMDA receptor induced ion currents.

Though these are the effects of LWDH, each of the component herbs is rarely studied. Interestingly, Corni Fructus has shown pro-apoptotic effect and up-regulation p53 in A549 lung cancer cell line (Choi et al., 2011). As described above, p53 up-regulation means there is vulnerability for damage in neuronal cells (Yonekura et al., 2006). Consequently, kidney tonifying herbal formula LWDH results in a decrease of $\mathrm{Ca}^{2+}$ ions and anti-apoptosis mediated by the Bcl family. It might be the same in neuronal death and might have a neuroprotective effect.

\section{CONCLUSION}

In traditional medical theory, as shown in the description above, there is no concept of neuronal cell death. The important thing is tonifying qi and the kidney when there is a brain deficiency 
which is a similar concept to neuronal cell death. The major herb of tonifying qi and major kidney tonifying herbal formulas, ginseng and LWDH, help to improve learning and memory, protect the body from NMDA induced excitotoxicity and p53 mediated neuronal cell death. In the past, traditional medicine standard treatment was decided based on many of the cases of neuronal death associated disease treatment with a variety of herbs or herbal formula, and in the end tonifying qi or the kidney was effective: the same as it is at present. Indeed, there are different application fields for ginseng and LWDH, but there are some overlapped in neuronal cell death fields. In other words, ginseng and LWDH usage are different, but there is a similar effect exerted on neurontal cell death.

In the neuroprotective effect, ginseng and LWDH have almost the same mechanism for mediated exertion. But most of the references are just shown and suggest what the main substance is, what the effect is, where it exists, when it acts, and its mechanism. The question needed to ask is why we divide and analysis materials. It is able to translate that ginseng and LWDH have neuroprotective from exctitoxicity, antiapoptotic and anti-oxidative effect to that tonifying qi or kidney is involved neuroprotective from exctitoxicity, anti-apoptotic and anti-oxidative effect in neuronal cell death associated disease. However, the similar effects of ginseng and LWDH on neuronal cell death did not divide what is qi and what is kidney in this review, but this will occur when sufficient references are gathered. Research in traditional medicine may be important not only in the study of traditional medicine material but also in gathering studies and applying traditional medicine, and it would be one of the methods to understand the practices of traditional medicine.

\section{ACKNOWLEDGEMENTS}

This research was supported by Kyung Hee University.

\section{CONFLICT OF INTEREST}

The authors have no conflicting financial interests.

\section{REFERENCES}

Aloyz RS, Bamji SX, Pozniak CD, Toma JG, Atwal J, Kaplan DR, Miller FD. p53 is essential for developmental neuron death as regulated by the TrkA and p75 neurotrophin receptors. J Cell Biol. 1998;143:1691-1703.

Anderson CN, Tolkovsky AM. A role for MAPK/ERK in sympathetic neuron survival: protection against a p53dependent, JNK-independent induction of apoptosis by cytosine arabinoside. J Neurosci. 1999;19:664-673.

Araki T, Enokido Y, Inamura N, Aizawa S, Reed JC, Hatanaka $\mathrm{H}$. Changes in c-Jun but not Bcl-2 family proteins in p53dependent apoptosis of mouse cerebellar granule neurons induced by DNA damaging agent bleomycin. Brain Res. 1998;794:239-247.

Banasiak KJ, Haddad GG. Hypoxia-induced apoptosis: effect of hypoxic severity and role of p53 in neuronal cell death. Brain Res. 1998;797:295-304.

Bao HY, Zhang J, Yeo SJ, Myung CS, Kim HM, Kim JM, Park JH, Cho J, Kang JS. Memory enhancing and neuroprotective effects of selected ginsenosides. Arch Pharm Res. 2005;28:335-342.

Bialik S, Geenen DL, Sasson IE, Cheng R, Horner JW, Evans SM, Lord EM, Koch CJ, Kitsis RN. Myocyte apoptosis during acute myocardial infarction in the mouse localizes to hypoxic regions but occurs independently of p53. J Clin Invest. 1997;100:1363-1372.

Chen RW, Chuang DM. Long term lithium treatment suppresses p53 and Bax expression but increases Bcl-2 expression. A prominent role in neuroprotection against excitotoxicity. J Biol Chem. 1999;274:6039-6042.

Chen RW, Saunders PA, Wei H, Li Z, Seth P, Chuang DM. Involvement of glyceraldehyde-3-phosphate dehydrogenase (GAPDH) and p53 in neuronal apoptosis: evidence that GAPDH is upregulated by p53. J Neurosci. 1999;19:9654-9662.

Chen XC, Zhou YC, Chen Y, Zhu YG, Fang F, Chen LM. Ginsenoside Rg1 reduces MPTP-induced substantia nigra neuron loss by suppressing oxidative stress. Acta Pharmacol Sin. 2005;26:56-62.

Cheng XR, Zhou WX, Zhang YX. The effects of Liuwei Dihuang decoction on the gene expression in the hippocampus of senescence-accelerated mouse. Fitoterapia. 2007;78:175-181.

Choi WH, Chu JP, Jiang MH, Baek SH, Park HD. Effects of fraction obtained from Korean Corni Fructus extracts causing anti-proliferation and p53-dependent apoptosis in A549 lung cancer cells. Nutr Cancer. 2011;63:121-129.

Crumrine RC, Thomas AL, Morgan PF. Attenuation of p53 expression protects against focal ischemic damage in transgenic mice. J Cereb Blood Flow Metab. 1994;14:887-891.

Dagher PC. Apoptosis in ischemic renal injury: roles of GTP depletion and p53. Kidney Int. 2004;66:506-509.

Donehower LA, Harvey M, Slagle BL, McArthur MJ, Montgomery CA Jr, Butel JS, Bradley A. Mice deficient for p53 are developmentally normal but susceptible to spontaneous tumours. Nature. 1992;356:215-221.

Eberspächer E, Werner C, Engelhard K, Pape M, Gelb A, Hutzler P, Henke J, Kochs E. The effect of hypothermia on the expression of the apoptosis-regulating protein Bax after incomplete cerebral ischemia and reperfusion in rats. $\mathrm{J}$ Neurosurg Anesthesiol. 2003;15:200-208.

Eberspächer E, Werner C, Engelhard K, Pape M, Laacke L, Winner D, Hollweck R, Hutzler P, Kochs E. Long-term effects of hypothermia on neuronal cell death and the concentration of apoptotic proteins after incomplete cerebral ischemia and reperfusion in rats. Acta Anaesthesiol Scand. 2005;49:477-487.

Engstrom FL, Woodbury DM. Seizure susceptibility in DBA and C57 mice: the effects of various convulsants. Epilepsia. 1988;29:389-395.

Enokido Y, Araki T, Aizawa S, Hatanaka H. p53 involves cytosine arabinoside-induced apoptosis in cultured cerebellar granule neurons. Neurosci Lett. 1996A;203:1-4.

Enokido Y, Araki T, Tanaka K, Aizawa S, Hatanaka H. Involvement of p53 in DNA strand break-induced apoptosis in

2011 / Volume 1 / Issue 1 / e1 
postmitotic CNS neurons. Eur J Neurosci. 1996B;8:1812-1821.

Ferraro TN, Golden GT, Smith GG, Berrettini WH. Differential susceptibility to seizures induced by systemic kainic acid treatment in mature $\mathrm{DBA} / 2 \mathrm{~J}$ and $\mathrm{C} 57 \mathrm{BL} / 6 \mathrm{~J}$ mice. Epilepsia. 1995;36:301-307.

Giaccia AJ, Kastan MB. The complexity of p53 modulation: emerging patterns from divergent signals. Genes Dev. 1998;12:2973-2983.

Greenblatt MS, Bennett WP, Hollstein M, Harris CC. Mutations in the p53 tumor suppressor gene: clues to cancer etiology and molecular pathogenesis. Cancer Res. 1994;54:4855-4878.

Gu B, Nakamichi N, Zhang WS, Nakamura Y, Kambe Y, Fukumori R, Takuma K, Yamada K, Takarada T, Taniura H, Yoneda Y. Possible protection by notoginsenoside R1 against glutamate neurotoxicity mediated by N-methyl-D-aspartate receptors composed of an NR1/NR2B subunit assembly. J Neurosci Res. 2009;87:2145-2156.

Gunasekar PG, Kanthasamy AG, Borowitz JL, Isom GE. NMDA receptor activation produces concurrent generation of nitric oxide and reactive oxygen species: implication for cell death. J Neurochem. 1995;65:2016-2021.

Halterman MW, Miller CC, Federoff HJ. Hypoxia-inducible factor-1alpha mediates hypoxia-induced delayed neuronal death that involves p53. J Neurosci. 1999;19:6818-6824.

Hertel M, Tretter Y, Alzheimer C, Werner S. Connective tissue growth factor: a novel player in tissue reorganization after brain injury? Eur J Neurosci. 2000;12:376-380.

Herzog KH, Chong MJ, Kapsetaki M, Morgan JI, McKinnon PJ. Requirement for Atm in ionizing radiation-induced cell death in the developing central nervous system. Science. 1998;280:1089-1091.

Hirata H, Cadet JL. p53-knockout mice are protected against the long-term effects of methamphetamine on dopaminergic terminals and cell bodies. J Neurochem. 1997;69:780-790.

Hsieh MT, Cheng SJ, Lin LW, Wang WH, Wu CR. The ameliorating effects of acute and chronic administration of LiuWei Dihuang Wang on learning performance in rodents. Biol Pharm Bull. 2003;26:156-161.

Hu RQ, Koh S, Torgerson T, Cole AJ. Neuronal stress and injury in C57/BL mice after systemic kainic acid administration. Brain Res. 1998;810:229-240.

Johnson MD, Xiang H, London S, Kinoshita Y, Knudson M, Mayberg M, Korsmeyer SJ, Morrison RS. Evidence for involvement of Bax and p53, but not caspases, in radiationinduced cell death of cultured postnatal hippocampal neurons. J Neurosci Res. 1998;54:721-733.

Jordán J, Galindo MF, Prehn JH, Weichselbaum RR, Beckett M, Ghadge GD, Roos RP, Leiden JM, Miller RJ. p53 expression induces apoptosis in hippocampal pyramidal neuron cultures. J Neurosci. 1997;17:1397-1405.

Kim JH, Cho SY, Lee JH, Jeong SM, Yoon IS, Lee BH, Lee JH, Pyo MK, Lee SM, Chung JM, Kim S, Rhim H, Oh JW,
Nah SY. Neuroprotective effects of ginsenoside Rg3 against homocysteine-induced excitotoxicity in rat hippocampus. Brain Res. 2007;1136:190-199.

Kim S, Kim T, Ahn K, Park WK, Nah SY, Rhim H. Ginsenoside $\operatorname{Rg} 3$ antagonizes NMDA receptors through a glycine modulatory site in rat cultured hippocampal neurons. Biochem Biophys Res Commun. 2004;323:416-424.

Kim S, Nah SY, Rhim H. Neuroprotective effects of ginseng saponins against $\mathrm{L}$-type $\mathrm{Ca}^{2+}$ channel-mediated cell death in rat cortical neurons. Biochem Biophys Res Commun. 2008;365:399-405.

Kim S, Rhim H. Ginsenosides inhibit NMDA receptormediated epileptic discharges in cultured hippocampal neurons. Arch Pharm Res. 2004;27:524-530.

Kleen JK, Holmes GL. Taming TLR4 may ease seizures. Nat Med. 2010;16:369-370.

Ko LJ, Prives C. p53: puzzle and paradigm. Genes Dev. 1996;10:1054-1072.

Kuntz C 4th, Kinoshita Y, Beal MF, Donehower LA, Morrison RS. Absence of p53: no effect in a transgenic mouse model of familial amyotrophic lateral sclerosis. Exp Neurol. 2000;165:184-190.

Lange-Asschenfeldt C, Kojda G. Alzheimer's disease, cerebrovascular dysfunction and the benefits of exercise: from vessels to neurons. Exp Gerontol. 2008;43:499-504.

Lee E, Kim S, Chung KC, Choo MK, Kim DH, Nam G, Rhim H. 20(S)-ginsenoside Rh2, a newly identified active ingredient of ginseng, inhibits NMDA receptors in cultured rat hippocampal neurons. Eur J Pharmacol. 2006;536:69-77.

Leker RR, Aharonowiz M, Greig NH, Ovadia H. The role of p53-induced apoptosis in cerebral ischemia: effects of the p53 inhibitor pifithrin alpha. Exp Neurol. 2004;187:478-486.

Leung KW, Yung KK, Mak NK, Chan YS, Fan TP, Wong RN. Neuroprotective effects of ginsenoside-Rg1 in primary nigral neurons against rotenone toxicity. Neuropharmacology. 2007;52:827-835.

Li W, Wang X, Liu B, Zhang Y, Deng J, Sun G. Preventing steroid-induced osteonecrosis of the femoral head with Liuwei dihuang pills and molecular mechanism. Zhongguo Xiu Fu Chong Jian Wai Ke Za Zhi. 2010;24:446-451.

Liu P, Xu B, Cavalieri TA, Hock CE. Pifithrin-alpha attenuates p53-mediated apoptosis and improves cardiac function in response to myocardial ischemia/reperfusion in aged rats. Shock. 2006;26:608-614.

Liu W, Fan YG, Xia XZ, Liu JR, Wang HB, Zeng YR. Human osteoblast-like cells OS-732 intervened with alcohol and treated with liuweidihuang pill medicated serum. Zhong Yao Cai. 2010;33:249-252.

Lowe SW, Schmitt EM, Smith SW, Osborne BA, Jacks T. p53 is required for radiation-induced apoptosis in mouse thymocytes. Nature. 1993;362:847-849.

Luo CX1, Zhu XJ, Zhang AX, Wang W, Yang XM, Liu SH, 
Han X, Sun J, Zhang SG, Lu Y, Zhu DY. Blockade of L-type voltage-gated $\mathrm{Ca}$ channel inhibits ischemia-induced neurogenesis by down-regulating iNOS expression in adult mouse. J Neurochem. 2005;94:1077-1086.

Malkin D, Li FP, Strong LC, Fraumeni JF Jr, Nelson CE, Kim DH, Kassel J, Gryka MA, Bischoff FZ, Tainsky MA, Friend SH. Germ line p53 mutations in a familial syndrome of breast cancer, sarcomas, and other neoplasms. Science. 1990;250:1233-1238.

Morrison RS, Kinoshita Y. The role of p53 in neuronal cell death. Cell Death Differ. 2000;7:868-879.

Morrison RS, Wenzel HJ, Kinoshita Y, Robbins CA, Donehower LA, Schwartzkroin PA. Loss of the p53 tumor suppressor gene protects neurons from kainate-induced cell death. J Neurosci. 1996;16:1337-1345.

Mosharov EV, Larsen KE, Kanter E, Phillips KA, Wilson K, Schmitz Y, Krantz DE, Kobayashi K, Edwards RH, Sulzer D. Interplay between cytosolic dopamine, calcium, and alphasynuclein causes selective death of substantia nigra neurons. Neuron. 2009;62:218-229.

Muir JK, Raghupathi R, Emery DL, Bareyre FM, McIntosh TK. Postinjury magnesium treatment attenuates traumatic brain injury-induced cortical induction of p53 mRNA in rats. Exp Neurol. 1999;159:584-593.

Nicholls D, Attwell D. The release and uptake of excitatory amino acids. Trends Pharmacol Sci. 1990;11:462-468.

Park E, Hwang I, Song JY, Jee Y. Acidic polysaccharide of Panax ginseng as a defense against small intestinal damage by whole-body gamma irradiation of mice. Acta Histochem. 2011;113:19-23.

Qi D, Zhu Y, Wen L, Liu Q, Qiao H. Ginsenoside Rg1 restores the impairment of learning induced by chronic morphine administration in rats. J Psychopharmacol. 2009;23:74-83.

Radad K, Gille G, Moldzio R, Saito H, Rausch WD. Ginsenosides $\mathrm{Rb} 1$ and $\mathrm{Rg} 1$ effects on mesencephalic dopaminergic cells stressed with glutamate. Brain Res. 2004;1021:41-53.

Ritz B, Rhodes SL, Qian L, Schernhammer E, Olsen JH, Friis S. L-type calcium channel blockers and Parkinson disease in Denmark. Ann Neurol. 2010;67:600-606.

Royle SJ, Collins FC, Rupniak HT, Barnes JC, Anderson R. Behavioural analysis and susceptibility to CNS injury of four inbred strains of mice. Brain Res. 1999;816:337-349.

Sakhi S, Bruce A, Sun N, Tocco G, Baudry M, Schreiber SS. p53 induction is associated with neuronal damage in the central nervous system. Proc Natl Acad Sci U S A. 1994;91:7525-7529.

Sakhi S, Sun N, Wing LL, Mehta P, Schreiber SS. Nuclear accumulation of $\mathrm{p} 53$ protein following kainic acid-induced seizures. Neuroreport. 1996;7:493-496.

Schauwecker PE, Steward O. Genetic determinants of susceptibility to excitotoxic cell death: implications for gene targeting approaches. Proc Natl Acad Sci U S A. 1997;94:4103-4108.

TANG / www.e-tang.org
Shin HT, Chung SH, Lee JS, Kim SS, Shin HD, Jang MH, Shin MC, Bahn GH, Paik EK, Park JH, Kim CH. Protective effect of shenqi-wan against $\mathrm{H} 2 \mathrm{O} 2$-induced apoptosis in hippocampal neuronal cells. Am J Chin Med. 2003;31:675-686.

Simon RP, Swan JH, Griffiths T, Meldrum BS. Blockade of Nmethyl-D-aspartate receptors may protect against ischemic damage in the brain. Science. 1984;226:850-852.

Smith ML, Kumar MA. The "Two faces" of Tumor Suppressor p53-revisited. Mol Cell Pharmacol. 2010;2:117-119.

Srivastava S, Zou ZQ, Pirollo K, Blattner W, Chang EH Germline transmission of a mutated p53 gene in a cancer-prone family with Li-Fraumeni syndrome. Nature. 1990;348:747-749.

Szeto YT, Lei PC, Ngai KL, Yiu AT, Chan CS, Kok EW, Leong CW. An in vitro study of the antioxidant activities and effect on human DNA of the Chinese herbal decoction 'Liu Wei Di Huang'. Int J Food Sci Nutr. 2009;60:662-667.

Tong G, Shepherd D, Jahr CE. Synaptic desensitization of NMDA receptors by calcineurin. Science. 1995;267:1510-1512.

Trimmer PA, Smith TS, Jung AB, Bennett JP Jr. Dopamine neurons from transgenic mice with a knockout of the p53 gene resist MPTP neurotoxicity. Neurodegeneration. 1996;5:233239.

Uberti D, Belloni M, Grilli M, Spano P, Memo M. Induction of tumour-suppressor phosphoprotein p53 in the apoptosis of cultured rat cerebellar neurones triggered by excitatory amino acids. Eur J Neurosci. 1998;10:246-254.

Van Kampen J, Robertson H, Hagg $\mathrm{T}$, Drobitch R. Neuroprotective actions of the ginseng extract G115 in two rodent models of Parkinson's disease. Exp Neurol. 2003; 184:521-529.

Verkhratsky A, Kirchhoff F. NMDA Receptors in glia. Neuroscientist. 2007;13:28-37.

Vogel KS, Parada LF. Sympathetic neuron survival and proliferation are prolonged by loss of p53 and neurofibromin. Mol Cell Neurosci. 1998;11:19-28.

Vousden KH, Prives C. Blinded by the Light: The Growing Complexity of p53. Cell. 2009;137:413-431.

Wang Y, Liu J, Zhang Z, Bi P, Qi Z, Zhang C. Antineuroinflammation effect of ginsenoside $\mathrm{Rbl}$ in a rat model of Alzheimer disease. Neurosci Lett. 2011;487:70-72.

Wennersten A, Holmin S, Mathiesen T. Characterization of Bax and Bcl-2 in apoptosis after experimental traumatic brain injury in the rat. Acta Neuropathol. 2003;105:281-288.

Wong VK, Cheung SS, Li T, Jiang ZH, Wang JR, Dong H, Yi $\mathrm{XQ}$, Zhou H, Liu L. Asian ginseng extract inhibits in vitro and in vivo growth of mouse lewis lung carcinoma via modulation of ERK-p53 and NF- $\mathrm{B}$ signaling. $\mathrm{J}$ Cell Biochem. 2010;111:899-910.

Wood KA, Youle RJ. The role of free radicals and p53 in neuron apoptosis in vivo. J Neurosci. 1995;15:5851-5857.

Xiang H, Hochman DW, Saya H, Fujiwara T, Schwartzkroin 2011 / Volume 1 / Issue 1 / e1 
PA, Morrison RS. Evidence for p53-mediated modulation of neuronal viability. J Neurosci. 1996;16:6753-6765.

Xiang H, Kinoshita Y, Knudson CM, Korsmeyer SJ, Schwartzkroin PA, Morrison RS. Bax involvement in p53mediated neuronal cell death. J Neurosci. 1998;18:1363-1373.

Xu H, Jiang H, Wang J, Xie J. Rg1 protects iron-induced neurotoxicity through antioxidant and iron regulatory proteins in 6-OHDA-treated MES23.5 cells. J Cell Biochem. 2010A;111:1537-1545.

Xu H, Jiang H, Wang J, Xie J. Rg1 protects the MPP ${ }^{+}$-treated MES23.5 cells via attenuating DMT1 up-regulation and cellular iron uptake. Neuropharmacology. 2010B;58:488-494.

Xue YM, Luo R, Zhu B, Zhang Y, Pan YH, Li CZ. Effects of liuwei dihuang pills on expressions of apoptosis-related genes bcl-2 and Bax in pancreas of OLETF rats. Zhong Xi Yi Jie He Xue Bao. 2005;3:455-458.

Yang S, Zhou W, Zhang Y, Yan C, Zhao Y. Effects of Liuwei Dihuang decoction on ion channels and synaptic transmission in cultured hippocampal neuron of rat. J Ethnopharmacol. 2006;106:166-172.

Ye R, Zhang X, Kong X, Han J, Yang Q, Zhang Y, Chen Y, Li P, Liu J, Shi M, Xiong L, Zhao G. Ginsenoside Rd attenuates mitochondrial dysfunction and sequential apoptosis after transient focal ischemia. Neuroscience. 2011;178:169-180.

Yonekura I, Takai K, Asai A, Kawahara N, Kirino T. p53 potentiates hippocampal neuronal death caused by global ischemia. J Cereb Blood Flow Metab. 2006;26:1332-1340.
You-Ping Zhu. Chinese Material Medica: Chemistry, Pharmacology and Applications. (Boca Raton, USA: CRC Press), pp. 549-557, 1998.

Youdim MB. Brain iron deficiency and excess; cognitive impairment and neurodegeneration with involvement of striatum and hippocampus. Neurotox Res. 2008;14:45-56.

Zhang X, Chen Y, Jenkins LW, Kochanek PM, Clark RS. Bench-to-bedside review: Apoptosis/programmed cell death triggered by traumatic brain injury. Crit Care. 2005;9:66-75.

Zhao H, Li Q, Pei X, Zhang Z, Yang R, Wang J, Li Y. Longterm ginsenoside administration prevents memory impairment in aged C57BL/6J mice by up-regulating the synaptic plasticity-related proteins in hippocampus. Behav Brain Res. 2009;201:311-317.

Zhao R, Zhang Z, Song Y, Wang D, Qi J, Wen S. Implication of phosphatidylinositol-3 kinase/Akt/glycogen synthase kinase$3 \beta$ pathway in ginsenoside Rbl's attenuation of beta-amyloidinduced neurotoxicity and tau phosphorylation. J Ethnopharmacol. 2011;133:1109-1116.

Zhao X, Wang Y, Sun Y. Simultaneous determination of four bioactive constituents in Liuwei Dihuang Pills by micellar electrokinetic chromatography. J Pharm Biomed Anal. 2007;44:1183-1186.

Zheng GQ, Cheng W, Wang Y, Wang XM, Zhao SZ, Zhou Y, Liu SJ, Wang XT. Ginseng total saponins enhance neurogenesis after focal cerebral ischemia. J Ethnopharmacol. 2011;133:724-728. 